The Economic Journal of Nepal, Vol. 42, No. 3 \& 4, July-December 2019 (Issue No. 152) C Cedecon-TU

\title{
Economic Cost of Absentee and Dropout Students in Public Schools of Nepal
}

\author{
Ram Rekha Roy ${ }^{1}$ \\ Bishnu Prasad Sharma ${ }^{2}$
}

\begin{abstract}
High absenteeism and dropout rates in school are considered one of the major stumbling blocks in achieving educational goals in developing countries. Absentees and dropouts impose a large resource cost on the educational system and the society. The study examines the economic cost of absentee and dropout students in public schools of Nepal. Using data from public schools in a rural municipality in Nepal, the study estimates the unit cost of absentee and dropout students by level. Cost of human resource, stationery, utility and fixed costs of building and furniture were the components for estimating unit costs. The findings reveal that the unit cost of students was equivalent to U.S. \$295, 130 and 143 for primary, lower-secondary, and secondary levels respectively, and an average of U.S. \$189 overall. The resource loss due to dropout was around 28, 12, and 11 percent of the total resource spent for primary, lower secondary and secondary levels respectively with an average of around 16 percent. The combined resource loss from dropouts and absentees were found to be 39, 23 and 20 percent for the different levels. On average, 26 percent of the public-school resource was lost due to dropouts and absentees. The main causes of dropout and absenteeism were the lack of interest, motivation of parents and the children to attend the school. The study suggests the need for more comprehensive and indepth study for effective policy formulation to address this problem.
\end{abstract}

Keywords: Unit cost of student, Dropout, Absentee, Resource loss

JEL Code: H52, I21, I22, I26

\section{Introduction}

High absenteeism and dropouts in schools are considered one of the major stumbling blocks in achieving educational goals in developing countries. Student dropout is an extreme case with permanent absenteeism (Gubbels et al., 2019). The percentage of students completing basic education level in Nepal is 71 percent while for grade twelve it is 22 percent (MoF, 2019). Student dropout imposes a huge wastage of resources spent on education and a burden on the hard-earned money of the taxpayers. Public schools provide the most effective and low cost avenue for human resource development and higher future income for the poor families. However, due to socio-economic factors, absenteeism and dropout rates among the poor are

\footnotetext{
${ }^{1}$ Mr. Roy is a teacher at Harihar Sarraf Champadevi Public School, Parsa, Nepal and M.A. Economics from Patan Multiple Campus, TU.

${ }^{2}$ Dr. Sharma is an Associate Professor at department of Economics, Patan Multiple Campus, Tribhuvan University, Nepal email: bishnu.sharma@pmc.tu.edu.np
} 
much higher. There is a large amount of literature available on the causes of school dropout (Hunt, 2008; Sabates et al., 2010; Kushiyat 2011; Gubbels et al., 2019). These factors have been categorized into individual-household factors, community factors and macro factors (Adelman \& Szekely, 2016). The major individual factors are poor health (or malnutrition) and motivation. Others emerge from children's household situation such as child labour and poverty. There are also school-related factors such as teachers, school location and poor quality of education among others (Sabates et al., 2010). A large body of literature is available on the consequences of school absenteeism and dropouts. Adelman and Szekely (2016) have emphasized the private and social cost of school dropouts in terms of the potential earning losses and the consequent impacts on the person's family and consequently social life. This paper aims to estimate the unit cost of student and the cost of student dropout at various levels of public schools with the purpose of measuring the magnitude of this loss. It also aims to broadly identify the factors responsible for student dropouts in the context of rural public schools.

The paper limits itself on the economic cost of student absenteeism and dropouts on the public schools and the government budget. The paper follows with a discussion on a few earlier studies on school dropouts with a focus on the economic cost. The methodology section discusses the sources of data, sampling design and the techniques of calculating the unit cost. The main findings present the findings of the study in accordance with the objectives of the paper. The discussion and conclusion sections deal with the broader context and point out the limitations of the paper along with some concluding remarks.

\section{Absenteeism, Dropout and Economic Costs}

The enhancement in labour productivity is the most direct pathway of public expenditure on education. Literature has identified that higher labour productivity results in higher income to the population and consequently, higher tax revenue to the government in the future. In that sense, public expenditure of education is an investment for future income of the society and revenue to the government. The effectiveness of public expenditure on education depends on its efficiency or low leakages in the system. Student dropouts are one such leakage in the system and reliable data on its magnitude is important for policy purpose. There is ample literature on the causes and consequences of student dropout. A study by Gubbels et al., (2019) examines the risk factors for school absenteeism and dropouts using a meta analytic review and identified 28 core school absenteeism risk domains and 23 dropout risk domains.

Likewise, Chugh (2011) has identified that dropout of children adds that risk factors prohibiting children's access to school that begin to add up even before students enrolling school. Family poverty, low level of parent's education, the weak family structure, pattern of schooling of children and lack of pre-school experiences are considered as the major ones. Poor family background and domestic problems create a negative environment, which affects the value of education of children. Children could also dropout as a result of a multitude of school factors such as uncongenial atmosphere, poor comprehension, absenteeism, negative attitude and behavior of the teachers and failure or repetition of students in the same grade. Rani (2011) in India found financial difficulties, child not interested in studies, parents not interested in studies, lack of education facilities in the nearby village, lack of quality education, imposition of parent's choices upon adolescence, lack of privacy and toilet facilities for girls in school and security reasons as reasons cited by adolescent for dropping out. Bridgeland et al., (2006) in the 
USA identified five major reasons why students drop out of school as including: a) Classes not interesting, b) Missed school for many days and couldn't coup with again, c) spent a lot time with those not interested in school, d) have absolute freedom to do what I like and, e) failing in school.

In a study in Nepal, Manandhar (2012) states that the overall primary school dropout rate was 4.26 percent in Chitwan and Nawalparasi districts. The dropout rate for girl (4.04 \%) was less than boy $(4.50 \%)$. More boys $(52.6 \%)$ dropped out than girls $(47.6 \%)$. Dalit caste comprised of around 30.5 percent of dropout children. The maximum $(42.2 \%)$ of the actual dropout was due to illiteracy and negligence of parents in the education of their children. From logistic regression analysis of child related variable, grade, age and work at home were found to be significant variable and among family related variables, parents apathy towards their children's education, education status of father, education status of mother, occupation status of father and number of children in family were found to be significant.

From the above literature, there is a great variation in the factors that causes dropout of students. Similarly, the cost of dropouts of students on the public education facility and the society at large also differ depending on several other factors. From an economic perspective, there are only limited studies on the economic cost of dropout students. Ngetich et al., (2014) for instance have examined the determinants of unit cost among secondary schools in Kenya. This study used primary data collected on several indicators and applied multiple regression method to determine the unit cost rather than directly collect cost of several cost components. This method was used for public schools and private schools with boarding facilities. The unit cost of public schools was higher than the unit cost of private schools. This method allows only indirect method of estimation of the cost of dropout students. This paper aims to contribute to existing literature methodologically, and by providing a measure of the magnitude of the problem based on empirical evidence.

\section{Methods}

This paper is based mainly on quantitative data complemented by some qualitative data. The data sources comprise of primary data collected from public schools at Thori Rural Municipality of Parsa District, Nepal. This municipality is located in central part of the southern belt along the Nepal India border.

\section{Sampling Design and Data Sources}

Thori Rural Municipality had altogether 25 public schools. The inclusion criteria were the selection of public schools in three levels-primary levels, lower-secondary level and the secondary level for comparison. Only five of the twenty-five schools in Thori Rural Municipality were secondary schools. The other schools were either lower secondary schools or higher secondary schools. These five schools were selected as the samples for the study. The necessary information was collected using structured questionnaire schedule from the records of these public schools such as school attendance, administrative records such as salary sheets and other financial records from the school management. Information was also collected from key informants such as the school headmaster, class teachers, administrative staffs, management committee members for which no official records were available.

The information on the number of enrollments, dropouts and absentee students were obtained from school attendance registers. Reasons for dropouts of individual students were 
obtained through class teachers and peers. The data was collected in the year 2017. It took around two months to collect the data. The analysis covers one academic year that completed in March 2017.

\section{Methods of Data Analysis}

The unit cost is the cost per unit of output-the completion of a given grade by a student in the present context. The cost comprises of fixed cost and variable cost. In the context of production of education, the variable costs are the cost of human resources (teaching and administrative staffs, cost of stationery, cost of utilities etc. while fixed costs are the costs of land and building, furniture and other fixed assets such as computers, laboratory and library facilities etc.

In the present study, the unit cost of students at various levels were constructed by breaking down the unit cost of the public schools into human resource costs (HRC), stationary costs (SC), utility costs (UC), and fixed costs (FC). The human resource cost comprised of the salaries of teachers and staff. These costs were distributed among various levels in proportion to the total class hours allocated to teachers at different levels. The salaries of staff were allocated to different levels by the number of students at different levels. The stationery costs were the costs of items such as duster, chalk or markers, registers, computer print papers and ink, teaching materials etc. The stationery costs were distributed in proportion to the number of students in different grades. The utility costs were the cost of water, electricity, telephone, internet and regular maintenance. The unit costs were distributed in proportion to the students at different levels.

The fixed cost is estimated as the opportunity cost of the land and buildings and furniture of the public schools. For this purpose, the rental values of the buildings were obtained by collecting information on what the present market value of the buildings would be if they were provided on rent for some other purpose. The annualized value of the furniture was calculated on the basis of the lifetime and present value of the existing furniture. Cost of land is not included in this study as most public schools are built on public land itself and this would also inflate the unit costs significantly. The total cost of the public schools was estimated using the relationship:

\section{Total Cost $(\mathrm{TC})=\mathrm{HRC}+\mathrm{SC}+\mathrm{UC}+\mathrm{FC}$}

Unit Cost (UC) of Student $=$ TC of the given level / total number of enrollments at that level Dropout Rate $=($ Dropout students at the given level*100)/total no of enrollments at a given level

Regarding the causes of dropouts, the potential causes were explored from available literature on school dropouts and were structured in the key informant interviews. Any additional reasons were incorporated in the key informant interviews. For estimating the cost of absenteeism, the students that dropped-out were first identified. For those students completing calendar year, total absent days were obtained from daily attendance registers of students. It was found that the total operational work-days in the public schools for that year were 192 days. The unit cost for enrolled students was divided by 192 days to obtain per day unit cost per student. The average absentee days was multiplied with the unit cost per day to obtain total resource loss due to absenteeism. This study has not been able to separate and deal with excused school days (e.g. due to sickness) and un-excused school days (e.g. due to delinquent behaviour (Gubbles et al., 2019). 


\section{Major Findings}

The educational levels in public schools were categorized into primary, lower secondary and secondary level. The primary level constituted of the first grade of entry called 'Early Child Development (ECD)' which is similar to play group followed by grade 1-5. The lower secondary level consisted of grades 6-8 while the secondary level comprised of grades 9-10. We discuss here the main findings of the study.

\section{Student Enrollment and Unit Costs at Different Levels}

The average students in the sampled secondary schools was 503 with around 24 percent at the primary level, 41 percent in the lower secondary level and 35 percent in the secondary level. The proportion of the students was small at the primary level. Primary level enrollments were very low. The key informant interview revealed that parents tried to start schooling of their children in private schools which often emphasized on English language learning that parents perceived would provide them with a comparative advantage in the globalized market. With increasing financial pressure and rise in the number of children, parents often have to transfer children from private schools to public schools at the lower secondary level that causes the percentage of students in the lower secondary level in public schools to swell.

Regarding the estimation of the costs, human resource cost comprised the highest share of around 85 percent (range 81-91\%) followed by fixed cost of around 8 percent (range 6-12\%) (See: Appendix-1). The other two components were stationery cost 4 percent (range 3-6\%) and utility cost of around 2 percent (range 1-5\%) on average but differed for three different levels. The average human resource costs were highest for the primary level which consisted of altogether 6 grades. The number of actual students enrolled at the primary level differed with a minimum of 29 students to 225 students in the sampled schools. It was found that some private schools were located more conveniently than the public primary schools which led to very poor primary level enrollments in them. Low actual enrollment but normal teacher allocation led to high resource costs.

The sampled schools had an average 22 teachers and staffs (Min. 18 and Max. 24). These schools had two to three administrative staffs consisting of one accounting staff and one or two supporting staffs. The student teacher ratio was found to be around 25 . The permanent teachers were paid a minimum of 25 thousand to 35 thousand rupees per month for 13 months a year (one-month festival bonus). Permanent teachers are also paid with pensions from government fund after their retirement. These pensions amount have not been included in this calculation due to complexities incurred in their calculations such as the total years the pension recipients would survive.

Table 1: Unit Cost of Students by Level of Public Schools (in \%)

\begin{tabular}{|l|c|c|c|c|c|}
\hline Level of School & $\begin{array}{c}\text { Total } \\
\text { Cost (Rs.) }\end{array}$ & $\begin{array}{c}\text { Human } \\
\text { Resource Cost }\end{array}$ & $\begin{array}{c}\text { Stationary } \\
\text { Cost }\end{array}$ & Fixed Cost & $\begin{array}{c}\text { Utility } \\
\text { Cost }\end{array}$ \\
\hline Primary & 30766 & 90.95 & 2.77 & 5.70 & 0.58 \\
\hline Lower Secondary & 13575 & 76.85 & 6.31 & 11.84 & 5.01 \\
\hline Secondary & 14913 & 81.12 & 5.74 & 11.75 & 1.38 \\
\hline \multicolumn{1}{|c|}{ Average } & $\mathbf{1 9 7 5 1}$ & $\mathbf{8 5 . 2 5}$ & $\mathbf{4 . 3 3}$ & $\mathbf{8 . 6 3}$ & $\mathbf{1 . 8 0}$ \\
\hline
\end{tabular}

Source: Field survey, 2017. 
The fixed costs were higher for lower secondary and higher secondary level. This indicates that primary education in rural areas are often provided in physical facilities that are poor in quality compared to their lower and lower secondary counterparts. The utility cost such as the cost of electricity and other facilities were also the lowest in case of primary schools. The overall cost estimation showed that human resource costs are the largest cost component while the utility costs are the smallest.

\section{Student Dropout Rates and Resource Costs on Public Schools}

The overall dropout rate of students in the sampled schools was around 16 percent with the highest dropout rates at the primary level followed by lower secondary level. This matches with the national rate of dropout for 2016. The dropout rates at the national level were 19.7 percent for primary level, 14.7 percent for lower secondary level and 10.9 percent for secondary level (MoE, 2016).

Table 2: Level-wise Resource Loss

\begin{tabular}{|l|c|c|c|c|c|}
\hline \multicolumn{1}{|c|}{ Level } & $\begin{array}{c}\text { No. of } \\
\text { Students }\end{array}$ & Dropout & $\begin{array}{c}\text { Dropout } \\
\text { in \% }\end{array}$ & $\begin{array}{c}\text { Annual / Student } \\
\text { Cost (NRs in } \\
\text { '000' }\end{array}$ & $\begin{array}{c}\text { Annual Resource } \\
\text { Loss (NRs in '000' }\end{array}$ \\
\hline Primary & 122 & 34 & 20.06 & 30.77 & 1046.04 \\
\hline L. Secondary & 205 & 25 & 10.65 & 13.58 & 339.38 \\
\hline Secondary & 176 & 19 & 10.22 & 14.91 & 283.35 \\
\hline Aggregate & 503 & 78 & - & - & 1668.77 \\
\hline Average & - & 26 & 13.64 & 19.75 & 556.26 \\
\hline
\end{tabular}

Note: (-) refers to not applicable

Source: Field survey, 2017.

The total resource loss was around NRs 1.7 million with 68 percent resource loss at the primary level followed by 22 percent at the lower secondary level and 18 percent at the secondary level. These indicate serious concerns for policy makers in retaining students at the primary level through new incentives on the part of both the students and parents to continue their studies. The total resource loss out of the total annual economic cost was 27.9 percent 12.2 percent and 10.8 percent respectively with an average loss of around sixteen percent.

\section{Causes of Student Dropouts in Public Schools}

Change of residence, student being a domestic worker and distance to school were the cause of dropout for none of the students. Lack of parent's interest was the strongest reason for student drop out. Lack of children's interest was the other important single factor followed by early marriage, bad performance in school and sickness. A multitude of other factors contributed 23 percent on the dropout factors. These comprised of search of job, love-affairs at an early age or poverty of the family, among others. The information from key informants revealed that poverty on the part of the parents and the low expectations from education led to the lack of parent's interest in sending their children to school. The low motivation on the part of the children had their problem in the language, lack of diversity in teaching learning activities and the household chorus children were engaged were also identified as factors causing low motivation on the part of the students. According to government records, the retention rates at 
grade eight are 77.9 percent and 58.5 percent for grade ten. It is only 22.2 percent for grade 12 . This implies that a large number of students drop out before completing their schooling.

\section{Resource Loss due to Absenteeism}

For estimating the resource loss of absentee students, the dropout number was deducted from the total enrollments. This gave the number of students completing the annual calendar of the grades. There are two possible outcomes, either they pass out or fail from graduating to higher grades. The government of Nepal has adopted a 'No-fail' policy for primary level and children are promoted to higher grade if they appear for the final exam at the end of the academic calendar. This study estimates only the cost of completing the annual calendar and the resource loss for those who fail in grades above grade 5 has not been captured in this study. The findings revealed that as students graduated to higher level, their absenteeism appears to be declining. The average absenteeism days were 30.0 days for primary level, around 24.6 days for lower secondary level and 20.4 days for secondary level students. It was found that the total workdays for public schools in the survey year were 192. The unit cost of absentee students per day was found to be NRs 160, 69 and 76 for primary, lower-secondary and secondary level respectively. The total resource loss due to absenteeism was obtained as a product of the number of students completing the calendar year and the unit price per day.

Figure 1: Average Resource Loss due to Absenteeism and Dropouts by Level of Schools

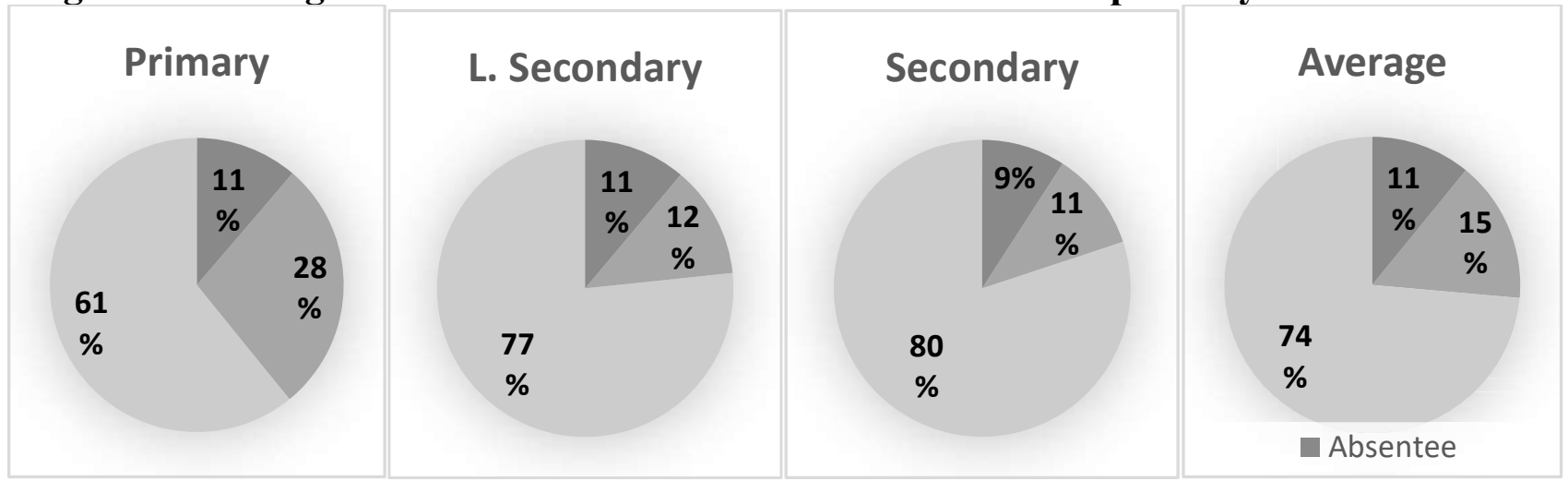

Source: Field survey, 2017.

The resource loss due to absenteeism was 11.3, 11.2 and 9.1 percent for primary, lowersecondary and secondary levels. The combined resource loss due to student dropout and absenteeism was found to be 39.2, 23.4 and 20 percent with an average 26.4 percent of resource loss by each public school.

\section{Discussions and Conclusions}

The findings revealed that the unit cost of students at the primary, lower secondary and secondary level were NRs. 30766, 13575 and 14913 respectively. The average resource cost for all levels was NRs. 19751. This is equivalent to U.S. \$295, 130 and 143 for the three levels respectively and an average of U.S. $\$ 189$ overall (1 U.S. $\$$ at 2017 prices $=$ NRs. 104.37; NRB, 2019). With an average of 503 students on average, the sampled public schools were spending around 95 thousand U.S. \$ per year. The resource loss due to dropout students was around 27.9 percent for primary level, 12.2 percent for lower secondary level and 10.8 percent for secondary level with an average of around 15.5 percent. 
The resource loss due to absenteeism was $11.3,11.2$ and 9.1 percent for primary, lowersecondary and secondary levels. The combined resource loss due to student dropout and absenteeism was found to be 39.2, 23.4 and 20 percent with an average 26.4 percent of resource loss by each public school.

The findings revealed that the resource loss was the highest almost 40 percent of the total public resources spent on primary level which is considered the most productive with a high return on public investment. Attainment of primary education enables workers to work more productively. This is substantiated by the fact that average wage premium for completing primary schooling was around 12.3 percent in seven countries in south east Asia (Thomas \& Burnett, 2015). The resource loss on the lower-secondary and secondary level is also substantially higher.

The effect of government expenditure on education on the economy has been found to be positive by a number of studies. A recent estimate by Appiah (2017) using panel data from 139 countries over a period 1975-2015 has shown that effect of education expenditures on per capita GDP is positive and statistically significant with a diminishing rate. The marginal effect has shown that increasing education expenditures by one percent contributes around 4.22 percent increase in per capita GDP. These findings have important policy implications for countries like Nepal where governments can improve the productivity of education by addressing the issue of school dropouts. Reduction in dropout and absenteeism contribute to reduce wastage of public expenditure in education and contribute to improve future labour productivity and income and consequently national income and per capita income.

A comprehensive study that covered 107 studies in low and middle income countries have found that conditional cash transfers are the most effective interventions in improving school participation while school feeding interventions contributed to both school participation and improving test scores (Snilstveit et al., 2016). Further studies with high methodological rigour have also proved this outcome (Damon et al., 2016). This provides evidence for public policy recommendation to address the absenteeism and drop problem to some extent.

The limited scope of the present study also indicates the need for a comprehensive study of the economic cost of school dropouts in public school. Such study can provide with the present level of unit cost of students in public schools by rural and urban category, ecological belts and other variations. Since the productivity of school level education is quite high, it is always important policy issue for the government to adopt appropriate policy measures to retain students at least till the school level.

\section{Limitations}

The study starts with a few words on the limitations of this study. While this study analyzes the resource cost of student dropouts, the potential lifetime income loss of the dropout student and the tax revenue loss to the government are beyond the scope of the study. Similarly, this study does not consider the opportunity cost of lost income due to school attendance in schools. This study also does not take into account the non-income benefit loss of school education such as improved health and civic engagements in the society. This study also does not cover the cost of students failing to graduate to higher level despite not dropping out from school. The other limitations are due to the small size of the sample and coverage of only one rural municipality. 


\section{References:}

Adelman, M., \& Szekely, M. (2016). School dropout in Central America: An overview of trends, causes, consequences, and promising interventions. The World Bank.

Appiah, E. N. (2017). The effect of education expenditure on per capita GDP in developing countries. International Journal of Economics and Finance, 9(10), 136-144.

Chugh, S. (2011). Dropout in secondary education: A study of children living in slums in Delhi. National University of Educational Planning: New Delhi.

Damon, A., Glewwe, P., Wisniewski, S., \& Sun, B. (2016). Education in developing countries-what policies and programmes affect learning and time in school? Expertgruppen för Bistånds Analys (EBA).

Gubbels, J., Van Der Put, C. E., \& Assink, M. (2019). Risk factors for school absenteeism and dropout: a meta-analytic review. Journal of Youth and Adolescence, 48(9), 1637-1667.

Hunt, F. M. (2008). Dropping out from school: A cross country review of literature. Consortium for Research on Educational Access, Transitions and Equity, University of Sussex, Centre for International Education, Research Monograph No 16

Kushiyait, B. K. (2011). School dropout and its relationship with quality of primary education in Nepal. Geographical Journal of Nepal, 23-32.

Manadhar, N. (2012). Determinant of primary school dropout in Chitwan and Nawalparasi. Thesis submitted for the degree of doctor of philosophy in Statistics submitted to Central Department of Statistics, T.U., Kirtipur: Kathmandu, Nepal.

MoE. (2016). Education in Figure - 2016 At-A-Glance, Government of Nepal, Ministry of Education, Educational Information Management Section, Singha Durbar; Kathmandu.

Ngetich, S. K., Wambua, B. K., \& Kosgei, Z. K. (2014). Determination of unit cost among secondary schools in Kenya: A case of Nandi North District, Kenya. European Scientific Journal, 10(16).

NRB (Nepal Rastra Bank) (2019). Quarterly Economic Bulletin, Nepal Rastra Bank, Mid-April 2019, vol 53, No. 3.

Sabates, R.; Westbrook, J.; Akyeampong, K., \& Hunt, F. (2010). School dropout: Patterns, causes, changes and policies.

Snilstveit, B., Stevenson, J., Menon, R., Phillips, D., Gallagher, E., Geleen, M., ... \& Jimenez, E. (2016). The impact of education programmes on learning and school participation in low-and middleincome countries.

https://repositorio.minedu.gob.pe/bitstream/handle/123456789/4892/The\%20impact $\% 20$ of $\% 20$ education \%20programmes $\% 20$ on $\% 20$ learning $\% 20$ and $\% 20$ school $\% 20$ participation $\% 20 \mathrm{in} \% 201 \mathrm{ow}-\% 20$ and \% 20middle-income $\% 20$ countries.pdf? sequence $=1 \&$ isAllowed $=\mathrm{y}$ Assessed: Nov 2,2019

Thomas, M., \& Burnett, N. (2015). The economic cost of out-of-school children in southeast Asia. United Nations Educational, Scientific and Cultural Organization. 


\section{Appendices}

Appendix-1: Unit Cost of Students by Level of Schools

\begin{tabular}{|l|c|c|c|c|c|c|}
\hline \multicolumn{1}{|c|}{ Level } & $\begin{array}{c}\text { No. of } \\
\text { Students }\end{array}$ & $\begin{array}{c}\text { Human } \\
\text { Resource Cost }\end{array}$ & $\begin{array}{c}\text { Stationery } \\
\text { Cost }\end{array}$ & $\begin{array}{c}\text { Fixed } \\
\text { Cost }\end{array}$ & $\begin{array}{c}\text { Utility } \\
\text { Cost }\end{array}$ & Total \\
\hline Primary & 122 & 27981 & 853 & 1753 & 179 & 30766 \\
\hline L. Secondary & 205 & 10432 & 856 & 1607 & 680 & 13575 \\
\hline Secondary & 176 & 12098 & 856 & 1753 & 206 & 14913 \\
\hline Aggregate & 503 & & & & & \\
\hline Average & 16.67 & 16837.07 & 855.05 & 1704.16 & 355.08 & 19751.36 \\
\hline
\end{tabular}

Source: Field survey, 2017.

Appendix-2: Average Resource Loss due to Absenteeism by Level of Schools

\begin{tabular}{|c|c|c|c|c|c|c|c|}
\hline Levels & $\begin{array}{c}\text { Total } \\
\text { Enrolled } \\
\text { Students } \\
\text { (A) }\end{array}$ & $\begin{array}{c}\text { Average } \\
\text { No. of } \\
\text { Dropout } \\
\text { (B) }\end{array}$ & $\begin{array}{c}\text { Average } \\
\text { No. of } \\
\text { Students } \\
\text { Completing } \\
\text { Level } \\
\text { (C=A-B) }\end{array}$ & $\begin{array}{c}\text { Average } \\
\text { Absentee } \\
\text { Days (D) }\end{array}$ & $\begin{array}{c}\text { Unit Cost } \\
\text { of Student } \\
\text { per year } \\
\text { (192 Work } \\
\text { Days) in } \\
\text { NRs. '000' }\end{array}$ & $\begin{array}{c}\text { Average } \\
\text { Daily } \\
\text { Cost (E) } \\
\text { NRs. }\end{array}$ & $\begin{array}{l}\text { Average Annual } \\
\text { Loss due to } \\
\text { Absentee } \\
\text { Students (F = } \\
\text { C*E) NRs. '000' }\end{array}$ \\
\hline Primary & 122 & 34 & 88 & 30.0 & 30766 & 160.40 & 423.45 \\
\hline $\begin{array}{c}\text { Lower } \\
\text { secondary }\end{array}$ & 205 & 25 & 180 & 24.6 & 13575 & 69.00 & 310.500 \\
\hline Secondary & 176 & 19 & 157 & 20.4 & 14913 & 76.27 & 2394.74 \\
\hline Aggregate & 503 & 78 & 425 & 25.0 & 19751 & 101.89 & 1082.55 \\
\hline
\end{tabular}

Source: Field survey, 2017.

Appendix-3: Average Resource Loss due to Absenteeism and Dropout by Level of Schools

\begin{tabular}{|l|c|c|c|}
\hline \multicolumn{1}{|c|}{ Levels } & $\begin{array}{c}\text { Average percent Resource } \\
\text { Loss due to Absentee Students }\end{array}$ & $\begin{array}{c}\text { Resource Loss percent } \\
\text { due to Dropout Students }\end{array}$ & $\begin{array}{c}\text { Percent Resource Loss due } \\
\text { to Dropout and } \\
\text { Absenteeism }\end{array}$ \\
\hline Primary & 11.28 & 27.87 & 39.15 \\
\hline L. secondary & 11.16 & 12.20 & 23.35 \\
\hline Secondary & 9.12 & 10.80 & 19.92 \\
\hline Average & 10.90 & 15.51 & 26.40 \\
\hline
\end{tabular}

Source: Field survey, 2017. 
Roy \& Sharma: Economic Cost of Absentee

Appendix-4: Causes of Dropouts by Level of Schools In percent

\begin{tabular}{|c|l|c|c|c|c|}
\hline $\begin{array}{c}\text { S. } \\
\text { N. }\end{array}$ & \multicolumn{1}{|c|}{ Causes of Dropout } & $\begin{array}{c}\text { Primary } \\
\text { Level }\end{array}$ & $\begin{array}{c}\text { Lower } \\
\text { Secondary }\end{array}$ & $\begin{array}{c}\text { Secondary } \\
\text { Level }\end{array}$ & Total \\
\hline 1 & Sickness & 0 & 5 & 1 & 2 \\
\hline 2 & Bad Performance & 0 & 5 & 0 & $\mathbf{2}$ \\
\hline 3 & Early Marriage & 0 & 17 & 34 & $\mathbf{1 4}$ \\
\hline 4 & Lack of Student's Interest & 24 & 25 & 11 & $\mathbf{2 1}$ \\
\hline 5 & Lack of parent's interest & 58 & 25 & 22 & $\mathbf{3 9}$ \\
\hline 6 & Others & 18 & 24 & 32 & $\mathbf{2 3}$ \\
\hline
\end{tabular}

Source: Field survey, 2017 